\title{
Akademik Umutsuzluk Ölçeği: Geliştirilmesi, Geçerlik ve Güvenirlik Çalışması
}

\author{
Murat GÖKALP ${ }^{1}$ ve Fatih SOYKAN ${ }^{2}$
}

\section{Öz}

$\mathrm{Bu}$ araştırma, öğrencilerin akademik umutsuzluk düzeylerindeki bireysel farklılıkların belirlenmesinde kullanılabilecek bir ölçme aracı geliştirmek ve geçerlik-güvenirliğini incelemek üzere yapılmıştır. Çalışma 2018-2019 eğitim öğretim yılları arasında üniversite düzeyindeki öğrencilerden elde edilen veriler üzerinden gerçekleştirilmiştir. Akademik Umutsuzluk Ölçeği 16 maddelik dörtlü Likert tipi bir ölçektir. Araştırmada genel tarama modeli kullanılmıştır. Ölçeğin iç tutarlılı̆̆ını belirlemek amacıyla hesaplanan Cronbach Alfa katsayısı .83'tür. Yap1 geçerliği saptamak amacıyla yapılan açımlayıcı faktör analizi sonucu toplam değişkenliğin \%48.3'ünü açıklayan üç faktör elde edilmiştir. Ortaya konulan üç faktörlü yapı doğrulayıcı faktör analiziyle sınanarak uyum ilişkisinin kabul edilebilir bir düzeyde olduğu belirlenmiştir. Geçerlik çalışması, söz konusu olan ölçeğin, akademik umutsuzluk düzeyinin birbirinden farklılaşması beklenen grupları birbirinden ayırt ettiğini göstermektedir. Akademik Umutsuzluk Ölçeği olarak adlandırılan ölçeğin, eğitim alanında kullanılabilecek, geçerli ve güvenilir bir araç olduğu belirlenmiştir.

Anabtar Sözcükler: Umutsuzluk, Akademik Umutsuzluk Ölçeği, Geçerlik, Güvenirlik

\section{Academic Hopelessness Scale: Development, Validity and Reliability Study}

\section{Abstract}

This research has been conducted to develop a measuring tool that can be used to determine individual differences of students' academic hopelessness levels and examine its validity and reliability. The study was conducted on the basis of data obtained university students of 2018-2019 academic years. The Academic Hopelessness Scale is Likerttype scale consisting of 16 item. General survey model was used to make this study. The Cronbach Alpha coefficient determines the internal consistency which is 0.83 .As a result of the search factor analysis conducted to determine the reliability, three factors were obtained and it was $48.3 \%$ of the total variability. It was revealed by using a three-factor structural confirmatory factor analysis and the relationship was at an acceptable level. The validity study shows that this scale distinguishes the groups which the level of academic hopelessness is expected to differ from each other.

Key Words: Hopelessness, Academic Hopelessness Scale, Validity, Reliability

\section{Atıf İçin / Please Cite As:}

Gökalp, M. ve Soykan, F. (2020). Akademik umutsuzluk ölçeği: Geliştirilmesi, geçerlik ve güvenirlik çalışması. Manas Sosyal Arasstirmalar Dergisi, 9(2), 741-751.

Geliş Tarihi / Received Date: 10.05.2019

Kabul Tarihi / Accepted Date: 14.10.2019

\footnotetext{
${ }^{1}$ Doç. Dr. - Ondokuz Mayıs Üniversitesi Eğitim Fakültesi Eğitim Bilimleri Bölümü, gokalpm@omu.edu.tr ORCID: 0000-0001-2345-6789

2 Psikolojik Danışman ve Rehber Öğretmen - Viranşehir Sertler Ortaokulu Viranşehir Şanlıurfa, fatihsoykann@hotmail.com ORCID: 0000-0001-9301-5284
} 


\section{Giriş}

Umutsuzluk, Türk Dil Kurumu tarafindan yayımlanmakta olan Güncel Türkçe Sözlükte 'umutsuz olma durumu, ümitsizlik, meyusiyet' olarak tanımlanmıştır (TDK, 2018). Umutsuzluk, bir amaca ulaşma yolunda sıfırdan daha az düzeyde olan olumsuz beklentiler şeklinde tanımlanmaktadır (Melges,1969, s.690699). Umutsuzluk, bireyin yaşayabileceği kararsızlık, mutsuzluk, suçluluk, çaresizlik duygularıly beraber görülebilmekte ve işlerini devam ettirememe gibi sorunlara da neden olabilmektedir. Bireylerin öz güvenlerinin az veya olmaması onların geleceğe karşı umutsuzluk duygularını artmasını etkileyebilmektedir (Dilbaz ve Seber, 1993, s. 134-138).

Umutta gerçekleştirilmesi hedeflenen planların başarılabileceği öngörüsünde bulunurken umutsuzlukta ise başarısızlık yönünde yargıya varılır (Uzbaş, 1998, s. 17-26).

Umut ve umutsuzluk iki farklı zıt durumları ifade eder. Bu iki kavram beklenti içinde olunan sonucun nasıl ve ne zaman gerçekleşebileceğine bağlı olarak duruma ve kişiye göre değişiklik gösterebilmektedir. Umut geleceğe yönelik yapılan planların başarıyla gerçekleştirebileceği öngörüsünü taşır iken umutsuzlukta ise bu planların başarılacağının mümkün olmadığı öngörüsü vardır (Ünal, 2006, s. 61).

Umutsuzluk, bir durum karşısında beklenti yönünün olumsuz olması başka bir deyişle beklentinin olumsuz yolda gittiği sanrısıdır. Asla gerçekleşmeyeceği düşüncesine sahip olunan beklentiler karşısında hissedilebilecek duygudur. Bireyin geleceğe yönelik negatif yargısını ifade eder (Ottekin, 2009, s. 11).

Umutsuzluk, kişiden bağımsız yollarla gelişen ve kişinin davranışları, olayın sonucunu değiştirmeyeceğine yönelik motivasyonel, duygusal ve bilişsel durumunu ortaya koyar. Kişinin olayları denetleyememesi, yeni davranışlarında motivasyonunu düşürmekte, daha önceki davranışlar ve olaylar arasında ilişki kuramaması yeni ögrenmelerini etkileyecektir ve tekrarlanan tecrübeler depresyona benzeyen duygulanımı yaratabilmektedir (Ünlüer, 2009, s. 15-16).

Umutsuzluk, kişinin ruh sağlığını negatif etkilerken, intihar ve depresyon gibi ruhsal problemlere yol açabilecek bir duygudur. 1986 yllında Kuzey Amerika Hemşirelik Tanılama Derneği (North America Nursing Diagnosis Association-NANDA) tarafindan umutsuzluk, bir hemşirelik tanısı olabilecek şekilde onaylanmış ve kişinin alternatifler göremediği veya bulamadığı aynı zamanda kendi yararına olsa da enerji sarf etmediği durum şeklinde ifade edebiliriz (Izgar, 2009, s. 16).

Umutsuzluk, insanların başarısızlıklarını hiçbir zaman üstesinden gelemeyeceklerine inanması, gerçek bir sebebi ortada yokken bile yaşantılarında yanlış anlamlar bulması, yaşadığı sorunları ne olursa olsun çözemeyeceğini düşünmesi ve amacına ulaşma yolunda bir gayret sarf etmediği halde bunlardan olumsuz sonuçlar beklemesi biçiminde açıklanabilir (Şahin, 2002, s. 143-144).

Umutsuzluk aslında hayata dair bir bakış açısıdır. Genel olarak bireyin geleceğe yönelik olumsuz beklentiler ve değerlendirmelerde bulunmasıdır. Hedeflerine asla ulaşamayacağı inancı, ileriye yönelik karamsar olmak ve yaşamakta olduğu problemlerin asla çözülemeyeceğine inanmak beraberinde umutsuzluğu getirmektedir (Erhan, 2005, s. 57-58).

Beck, daha önce intihar girişimine kalkışmış depresif belirtisi olan hastalar ile yaptığ araştırmalar sonucu hastaların sorunlarına bir çözüm bulunmadığına ve bulunmayacaklarına yönelik inançları ile intihar girişimi arasında sıkı bir ilişki olduğunu ortaya koymaktadır. Hasta mantığa uygun bir neden olmadığı halde amacına yönelik bir uğraş içine girmediği halde sonucunun negatif olacağını beklemektedir. Beck hastalarda yaşanan durumu umutsuzluk olarak ifade etmiştir (Abramson vd., 1989, s. 358).

Umutsuzluk, tedavisi mümkün olan ve korunulabilen ruhsal bir sorundur. Bu problemlere neden olan ilk belirtilerin tüm bireylerce bilinmesi, yardımcı olabilecek servis sayısının arttırılması, toplumun ruh sağlığının güvence altına alınması ve düzeltilmesinde önemli bir yer teşkil etmektedir (Tümkaya, 2005, s. 454-455).

Günümüzde üniversite dediğimiz oluşum toplumun ekonomik, kültürel, sosyal, teknolojik ve bilimsel gelişiminde önemli rol oynar. Üniversiteler çeşitli yaşam alanlarından oluşmaktadır ve bunlardan birisi de akademik boyutudur. Bu akademik kısmın temel girdisi ise öğrencilerdir. İnsanların sahip olduğu kültürel, toplumsal konumu ve doğası gereği kendisine özgü yaşam planları oluşturmaktadır. Öğrenciler açısından baktı̆̆ımızda beklenti ve planlarının karşılanma düzeyi onların başarılarını ve umut düzeylerini etkilemektedir. Bu beklenti ve planlar karşılanmadığı anlarda şikayetler, doyumsuzluklar ve umutsuzluklar ortaya çıkabilmektedir (Firat, Şahin ve Zoraloğlu, 2011, s. 433). 
Literatür taraması sonucunda doğrudan akademik umutsuzluğu ölçen bir ölçme aracina rastlanmamıştır. Bu durum gerçekleştirilen bu çalışma için önemli düzeyde zorlayıcı olmuştur. Geliştirilen' Akademik Umutsuzluk Ölçeği'nin öğrencilerin yaşayabilecekleri olası akademik umutsuzluk duygusunu ölçmede katkı sağlayacağı umulmaktadır.

\section{Yöntem}

Öğrencilerin akademik umutsuzluk düzeylerini belirlemek amacıyla hazırlanan ölçeğin geliştirilmesi sürecinde, genel tarama modeli kullanılmıştır.

\section{Araştırmanın Amacı}

$\mathrm{Bu}$ araştırma, öğrencilerin akademik umutsuzluk düzeylerindeki bireysel farklılıkların belirlenmesinde kullanılabilecek bir ölçme aracı geliştirmek ve geçerlik-güvenirliğini incelemek üzere yapılmıştır.

\section{Akademik Umutsuzluk Ölçeği'nin Geliştirilmesi}

Ölçeğin geliştirilmesinde aşağıdaki süreçler izlenmiştir.

\section{Çalışma Grubu}

Bu ölçeğin geliştirilmesi sürecinde 2018-2019 eğitim öğretim yılları arasında Samsun ilinden tesadüfi örneklem yolu ile seçilmiş Ondokuz Mayıs Üniversitesinin çeşitli fakültelerinde öğrenim görmekte olan 310 öğrenci üzerinde gerçekleştirilmiştir. Çalışmaya katılan öğrenci seçimlerinde, özellikle ekonomiklik ve ulaşılabilirlik dikkate alınmıştır. Üniversite düzeyindeki öğrenci grupları arasından çalışmaya katılan 310 öğrenci çalışma grubunu oluşturarak ele alınmıştır. Bu örneklem yolu ile elde edilen veriler üzerinden araştırma gerçekleştirilmiştir $(\mathrm{N}=310)$. Yaş aralıkları ise 18-25 arasında değişkenlik göstermektedir.

\section{Ölçeğin Geliştirilmesiyle İlgili Çalışmalar}

Akademik Umutsuzluk Ölçeği'ne konulacak maddelerin hazırlanmasında birçok farklı yol kullanılmıştır. Maddelerin hazırlanmasına yönelik olarak Ondokuz Mayıs Üniversitesi Eğitim Fakültesi öğrencileriyle yapılandırılmamış 10'ar dakikalık görüşmeler yapılmıştır. Bu görüşmeler sırasında, yalnızca ögrencilerin umutsuzluk kavramına ilişkin bakış açılarıyla birlikte kendilerine ait kullanmış oldukları dil anlaşılmaya çalışılmıştır.

Bu öğrencilerin görüşleri dikkate alınarak incelemenmiş ve gerekli düzenlemeler ile maddeler haline getirilmiştir. Hazırlanan maddeler yalnızca doğrudan ifadelerin düzeltilmesi ile kısıtlı kalmamış, öğrencilerin sundukları verilerin bütünlüğ̈ araştırmaciya yeni maddeler yazabilme konusunda firsat da vermiştir. Maddelerin hazırlama aşamasında yukarıda belirtilen yollara artı olarak literatürün taranması sonucu umutsuzluk kavramından elde edilen bilgileri madde haline getirme ve de konuyla ilgili benzer ölçeklerdeki maddeleri inceleme yöntemi de kullanılmıstır. Deneme olarak kullanılacak madde sayılarının olabildiğince çok olmasına dikkat edilmeye çalışılmıştır. Bu şekilde 64 ifade ile madde havuzu oluşturulmuştur.

İlk aşamada 64 maddelik uzman görüşü anket formu hazırlanarak, Ondokuz Mayıs Üniversitesinde görev yapmakta olan ikisi Rehberlik ve Psikolojik Danışma, dördü de Eğitim Programları ve Öğretimi alanında çalışan 6 uzman tarafindan ifade, şekil, biçim ve umutsuzluk göstergesi olup olmadığı yönünden incelenmiştir. Uzmanlardan edinilen bilgi ve tavsiyeler doğrultusunda gerekli olan düzeltmeler yapılmıştır. Düzenlemeler sonucunda 20 madde ölçekten çıkartılarak 44 maddelik pilot uygulama ölçek formu hazırlanmıştır.

İkinci aşamada, Ondokuz Mayıs Üniversitesi Eğitim Fakültesinde öğrenim görmekte olan 50 kişilik bir gruba 44 maddelik pilot uygulama ölçek formu uygulanarak testin madde-test korelasyonu ve iç tutarllık katsayısı hesaplanmıştır. Madde-test korelasyonunun belirlenmesiyle korelasyon katsayısı .30'un altında olan maddeler elenerek ölçekteki madde sayısı 30'a düşürülmüştür. Son aşamaya gelindiğinde 30 maddelik ölçek 1 ile 4 arasında derecelendirilerek Likert tipi ölçek hazırlanmıştır. Ölçeğin geçerlik ve güvenirlik incelenmesi Ondokuz Mayıs Üniversitesinin çeşitli fakültelerinde öğrenim gören 310 kişiden oluşan bir öğrenci grubu üzerinde gerçekleştirilmiştir. Geçerlik çalışmasında Açımlayıcı Faktör Analizi ve Doğrulayıcı Faktör Analizi kullanılmıştır. Güvenirlik için, Cronbach alfa iç tutarlık katsayısı bulunmuştur.

Yukarıda özellikleri verilmiş veriler üzerinde gerçekleştirilen analizler, asıl ölçek maddelerini ve buradaki maddelerin özelliklerini belirlemek amacı ile yapılmıştır. Önce bu 44 maddeden madde toplam korelasyonuna dayanarak madde seçilmiş, toplam puanla .30’un altında ilişki gösteren 14 madde faktör 
analizine alınmamıştır. Sonrasında kalan 30 madde arasındaki olası en uygun yapıyı ortaya çıkarmak amacıyla, açımlayıcı faktör analizi ve doğrulayıcı faktör analizi kullanılmıştır. Faktör analizinin ortaya koyduğu yapı içinde yer alan maddelerin madde analizleri yapılmıştır.

\section{Veri Toplama Araçları}

\section{Akademik Umutsuzluk Ölçeği}

Akademik Umutsuzluk Ölçeği, bireyin akademik umutsuzluğunu davranışsal, bilişsel ve çevresel alt boyutlarıyla belirlemek amacıyla geliştirilmiştir.

Ölçek toplam 16 madde ve üç alt boyuttan oluşmaktadır. Öğrencilerin akademik umutsuzluklarına ilişkin ifadeler verilip, bunları ne kadar sıklıkla yaşadıklarına dair 1-4 arasında, (4) Her zaman, (3) Genellikle, (2) Nadiren, (1) Hiçbir zaman şeklinde derecelendirmeleri istenmektedir. Ölçeğin genelinden alınabilecek en yüksek puan 64 , en düşük puan ise 16 'dır.

Akademik Umutsuzluk Ölçeği'nin içerdiği madde sayıları ve alt ölçeklerinin tanımlanması şu şekildedir:

Davranışsal: Öğrenmek adına çaba sarf etmek, problem çözmek, sorunları çözmek için gayret göstermek ve farklı yollar denemek gibi belirtiler şeklinde kendini gösterir. Bu alt boyuttan alınabilecek en yüksek puan 28 , en düşük puan ise, $7^{\prime}$ dir. Bu alt boyut 7 maddeden oluşmaktadır.

Bilişsel: Başarılı olma inancı, geleceğe bakış açısı, hatalı düşünceler, beklentiler, unutma, rahatsız edici durumlar şeklinde görülür. Bu alt boyuttan alınabilecek en yüksek puan 16, en düşük puan ise, 4 'tür. Bu alt boyut ise, 4 maddeden oluşmaktadır.

Çevresel: Öğretmene ulaşılabilirlik, mesleki ilişkiler, zaman ve aile ile iletişim şeklinde kendini gösterir. Bu alt boyuttan alınabilecek en yüksek puan 20, en düşük puan ise, 5'tir. Bu alt boyut da 5 maddeden oluşmaktadir.

\section{İşlem Yolu}

Akademik Umutsuzluk Ölçeği, üniversite düzeyi öğrenciler tarafından uygulanmıştır. Üniversite öğrencilerinden uygulamaya katılmaya gönüllü olan bireylere, uygulamalar yapılmadan önce maddelere ne şekilde cevap verecekleri ve araştırmanın amacına yönelik bilgiler açıklanmıştır.

\section{Verilerin Analizi}

Akademik Umutsuzluk Ölçeği'nin güvenirliği Cronbach Alfa iç tutarlık katsayısı hesaplanarak incelenmiştir. Geçerlik çalışmasında ise yapı geçerliği için Açımlayıcı Faktör Analizi ve Doğrulayıc1 Faktör Analizleri uygulanmıştır. Verilerin analizinde SPSS 17.0 paket programı ve IBM SPSS AMOS 22 kullanılmıştır.

\section{Bulgular}

$\mathrm{Bu}$ bölümde geliştirilmesi amaçlanan Akademik Umutsuzluk Ölçeği'nin madde-toplam puan korelasyonları, güvenirlik ve geçerlik hesaplamalarına ilişkin bulgulara yer verilmiştir.

\section{Akademik Umutsuzluk Ölçeği Madde Analizleri}

Geliştirilmeye çalışılan Akademik Umutsuzluk Ölçeği'nin gerek faktör düzeyindeki yapısı olsun, gerekse toplamdaki durumunu görmek adına öğrencilerin her bir maddeden aldıkları puanlar ile ölçek toplam puanları ve faktör toplam puanları arasındaki düzeltilmiş madde toplam korelasyonları belirlenmiştir. Bununla beraber, maddelerin ayrı ayrı faktör içerisinde ve toplam puanları esas alınarak Cronbah Alfa güvenirlik katsayıları da hesaplanmıştır. Sonuçlar Tablo 1 de gösterilmektedir. 
Tablo 1. Faktörler ve Toplamda Düzeltilmiş Madde Toplam Korelasyonlar ile Cronbach Alfa (Güvenirlik) Değerleri

\begin{tabular}{|c|c|c|c|c|}
\hline Madde No & $\begin{array}{c}\text { Faktör } \\
\text { (Davranışsal) } \\
\end{array}$ & $\begin{array}{lc}1 & \begin{array}{c}\text { Faktör } \\
\text { (Bilişsel) }\end{array} \\
\end{array}$ & 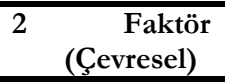 & Toplam \\
\hline 21 & .60 & & & .55 \\
\hline 20 & .58 & & & .55 \\
\hline 26 & .63 & & & .60 \\
\hline 25 & .60 & & & .60 \\
\hline 24 & .54 & & & .53 \\
\hline 27 & .37 & & & .34 \\
\hline 6 & .32 & & & .30 \\
\hline 9 & & .61 & & .50 \\
\hline 11 & & .49 & & .38 \\
\hline 22 & & .51 & & .44 \\
\hline 5 & & .55 & & .57 \\
\hline 8 & & & .39 & .36 \\
\hline 30 & & & .42 & .41 \\
\hline 15 & & & .33 & .31 \\
\hline 4 & & & .42 & .37 \\
\hline 3 & & & .36 & .48 \\
\hline Cronbach Alfa & .78 & .74 & .63 & .83 \\
\hline
\end{tabular}

Tablo 1 de ulaşılan sonuçlara göre tek tek maddelerin içinde bulunmuş olduğu faktör toplamı ile anlamlı korelasyonlar göstermektedir. Bununla birlikte toplam puan ile de anlamlı ve birçok madde de daha yüksek korelasyon göstererek karşımıza çıkmaktadır. Ayrıca toplam için analiz edilen Cronbach alfa değeri, ayrı ayrı üç faktör için de hesaplanan Cronbach alfa değerinden büyük çıktığı bulunmuştur. Bu analiz sonuçları gösteriyor ki geliştirilen ölçeğin tek faktörlü, aynı zamanda da çok faktörlü biçimde kullanılabileceğini ortaya koymaktadır.

\section{Akademik Umutsuzluk Ölçeği Güvenirlik Çalışması}

Akademik Umutsuzluk Ölçeği'nin iç tutarlık güvenirliği belirlemek amacıyla Cronbach alfa katsayısı hesaplanmıştır. 16 maddelik ölçeğin iç tutarlık (Cronbach alfa) katsayısı .83 olarak bulunmuştur. İlgili literatürde .70 Cronbach Alpha katsayısı geliştirilmeye çalışılan ölçme aracının güvenilir olmasına yönelik kabul edilebilir bir sınır noktası olarak ifade edilmiştir (Creswell, 2012, s. 146-166). Analiz sonucunda bulunan $.83^{\prime} l u ̈ k$ Cronbach alfa değeri Akademik Umutsuzluk Ölçeği'nin güvenirlik seviyesi için yeterli ve kabul edilir düzeyde olduğu görülmektedir.

Akademik Umutsuzluk Ölçeği'nin alt ölçeklere yönelik Cronbach Alpha iç tutarlık katsaylları ise, Davranışsal alt ölçeği için .78, Bilişsel alt ölçek için .74 ve Çevresel alt boyut için .63 olarak ortaya konulmuştur. Ölçme aracının iç tutarlılık katsayıları hesaplandığında çevresel alt faktörünün Cronbach Alpha değerinin sınır olarak belirlenen .70 değerinden düşük bulunduğu karşımıza çıkmaktadır. Çevresel alt faktörde yer alan madde sayısının az olması (beş madde) iç tutarlık değerinin belirtilen alt boyut için düşük değer almasina neden olarak gösterilebilmektedir. Şencan (2005, s.562-590), geliştirilen bir ölçme aracının alt faktörlerle ilişkin iç tutarlık katsayısının .60 seviyesinin kesim noktası olmasının güvenirlik için makul olabileceğini belirtmektedir.

Ortaya konulan bu değerlere bakıldığında Akademik Umutsuzluk Ölçeği'nin güvenirlik düzeyi için yeterli olduğu sonucuna varılabilmektedir. Tablo 2'de Akademik Umutsuzluk Ölçeği'nin güvenirliğine iliş̧kin bilgiler verilmektedir.

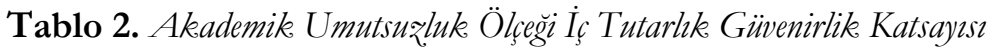

\begin{tabular}{ll}
\hline Cronbach Alfa & Madde Sayıs1 \\
\hline .838 & 16 \\
\hline
\end{tabular}

\section{Akademik Umutsuzluk Ölçeği Geçerlik Çalışması}

\section{Açımlayıcı Faktör Analizi (AFA)}

Faktör analizi süresince ölçekte bulunan maddelerin analizlerine yönelik uygunluğunun ortaya konulması için Barlett Sphericity ve Kaiser-Meyer-Olkin (KMO) testlerinin analiz edilmesi gerekmektedir (Odacı, Kalkan ve Çıkrıkçı, 2017, s. 356). KMO katsayısının .87 olarak hesaplandığı ölçek ile ilişkili Barlett Sphericity testinin anlamlı olduğu bulunmuştur. Ulaşılan bulgulara bakılarak, elde edilen veriler ve 
örneklem büyüklügü faktör analizi için uygun olduğunu göstermektedir. Tablo 3’te KMO ve Barlett's testi ile ilgili bilgilere yer verilmiştir.

Tablo 3. KMO ve Barlett's Testi

\begin{tabular}{lll}
\hline \multicolumn{2}{l}{ Kaiser-Meyer-Olkin Measure of Sampling Adequacy } & .879 \\
\hline \multirow{3}{*}{ Bartlett's Test of Sphericity } & \multicolumn{1}{l}{ Approx. Chi-Square } & 1307.691 \\
\cline { 2 - 3 } & $\mathrm{df}$ & 120 \\
\cline { 2 - 3 } & Sig. & .000 \\
\hline
\end{tabular}

Akademik Umutsuzluk Ölçeği'nin alt boyutlarını belirleyebilmek ve faktör yapısını incelemek amacıyla temel bileşenler analizi ve Direct Oblimin döndürme tekniği uygulanmıştır. Direct Oblimin döndürme tekniği sonucu faktör yükü .30'un üzerinde çıkan maddelerin faktörlere dağılması sağlanmıştr.

30 madde üzerinden faktör analizi uygulanmıştır ve birden çok faktörde birbirinden ayırt edilemeyecek kadar yakın yükler alan ya da hiçbir faktörde yer almayan maddeler analizden çıkarılarak analiz tekrar gerçekleştirilmiştir. Scree test yapılarak grafik eğrisinin eğiminde meydana gelen ilk ani değişikliğe kadar olan faktörlerin seçilmesi ve faktör sayılarının azaltılması gerekmektedir. Scree testin ardından elde edilen grafiğe bakılarak ilk ani değişikliğin üçüncü faktörde olduğu görülmüştür. Scree test sonuçlarına göre dayandırılarak üç faktörde toplandırılmasına yönelik Direct Oblimin döndürme tekniği gerçekleştirilmiştir. Hesaplamalarda işleme alınan 30 maddeden 16'sının yukarıda belirtilen ölçütlerle uyumlu olduğu saptanılmıştır. Geriye kalan 16 madde 3 faktör altında toplanmıs ve herhangi bir madde dışarıda kalmamıştır.

Tablo 4. Scree Plot

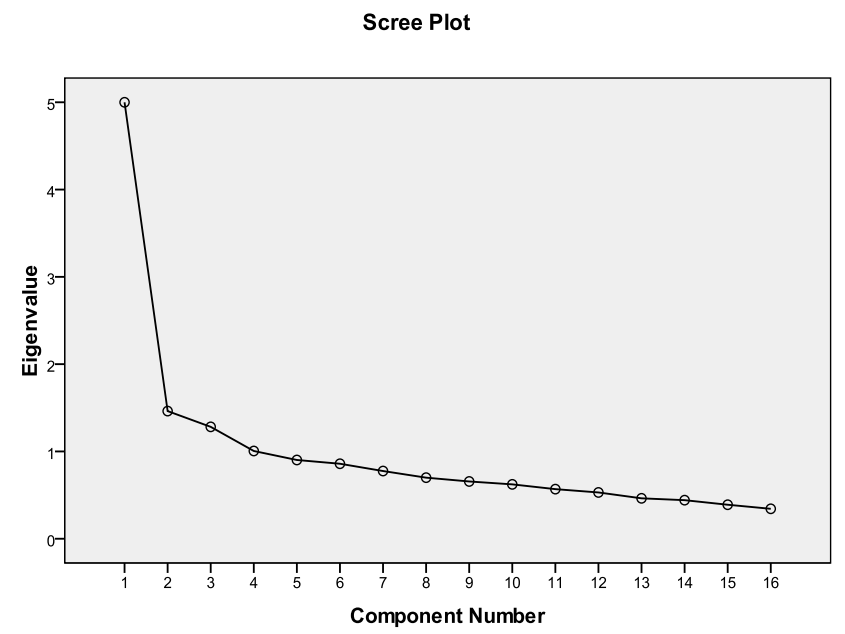

Tablo 5'te karşımıza çıktı̆ı gibi tüm faktörler toplam varyansın \% 48.399 açıklamaktadır. Ölçekteki maddelerin faktör yükleri ise .477 ile .791 arasında farkllık göstermektedir.

Akademik Umutsuzluk Ölçeği'nin üç faktörünün açıkladıkları toplam varyans \% 48.399'dur. Davranışsal boyut kısmını yansıtan ve 7 maddeden oluşan birinci faktör toplam varyansın \% 31.248'i, bilişsel boyutu yansitan ve 4 maddeden oluşan ikinci faktör toplam varyansin \% 9.140'1nı ve son olarak çevresel boyutu yansıtan ve 5 maddeden oluşan üçüncü faktör toplam varyansın \% 8.011'ini açıklamış olduğu bulunmuştur. 
Tablo 5. Akademik Umutsu₹luk Ölçeğg'nin Faktör Analiz. Sonuclar

\begin{tabular}{|c|c|c|c|c|}
\hline $\begin{array}{l}\text { Madde } \\
\text { No }\end{array}$ & $\begin{array}{c}\text { Faktör } 1 \text { (Davranışsal) } \\
\text { Açıklanan Varyans } \\
\% 31.248\end{array}$ & $\begin{array}{c}\text { Faktör 2 (Bilişsel) } \\
\text { Açıklanan Varyans } \\
\% 9.140\end{array}$ & $\begin{array}{c}\text { Faktör } 3 \text { (Çevresel) } \\
\text { Açıklanan Varyans } \\
\% 8.011\end{array}$ & $\begin{array}{c}\text { Toplam } \\
\text { Açıllanan Varyans } \\
\% 48.399\end{array}$ \\
\hline 21 & .748 & & & \\
\hline 20 & .703 & & & \\
\hline 26 & .672 & & & \\
\hline 25 & .659 & & & \\
\hline 24 & .601 & & & \\
\hline 27 & .595 & & & \\
\hline 6 & .477 & & & \\
\hline 9 & & .791 & & \\
\hline 11 & & .757 & & \\
\hline 22 & & .686 & & \\
\hline 5 & & .632 & & \\
\hline 8 & & & .683 & \\
\hline 30 & & & .661 & \\
\hline 15 & & & .578 & \\
\hline 4 & & & .535 & \\
\hline 3 & & & .484 & \\
\hline
\end{tabular}

Faktörlerin açıklamış olduğu varyanslar ve faktörler altında yer alan maddelerin içeriklerine bakıldığında ölçeğin hem üç faktörlü hem de tek boyutlu biçimde kullanılabileceğini göstermektedir. Bu açıdan olacak ki madde analizleri hem toplam hem de faktör üzerinden yapılmıştır.

Üç alt boyuttan oluşan Akademik Umutsuzluk Ölçeği 16 maddeden oluşup, her bir madde yanıtlayıcıya kendisine uygun olup olmadığı bakımından dörtlü dereceleme şansı sunmaktadır. Ölçekte 1 madde olumsuz puanlanırken, 15 maddenin puanlamasında tersine çevirmek gerekmektedir. Ölçeğin uygulama sonucunda alınabilecek olan minimum puan 16 ve maksimum puan 64'tür. Puanın yüksekliği, akademik umutsuzluk düzeyinin yüksekliğini işaret eder.

\section{Doğrulayıcı Faktör Analizi (DFA)}

Doğrulayıc1 faktör analizi (DFA) Akademik Umutsuzluk Ölçeği'nin faktör yapısının geçerliği hesaplanması amacıyla uygulanmıştır. Doğrulayıcı faktör analizi, oluşturulmuş faktörlerin gerçek veriler ile ne düzeyde tutarlı olduğunu ortaya koymak için uygulanmaktadır (Kline, 2011, s.690-699). Geliştirilmeye çalışlan bu ölçek modelinin uyum düzeyinin belirlenmesinde CFI (Comparative Fit Indices), AGFI (Adjusted Goodness of Fit Index), GFI (Goodness of Fit Index), SRMR (Standardized Root Mean Square Residual), NNFI (Non-Normed Fit Index), RMSEA (Root Mean Square Error of Approximation) gibi uyum verilerinden yararlanılmıştır.

Tablo 6. Doğrulayıc Faktör Analizi Diyagramı

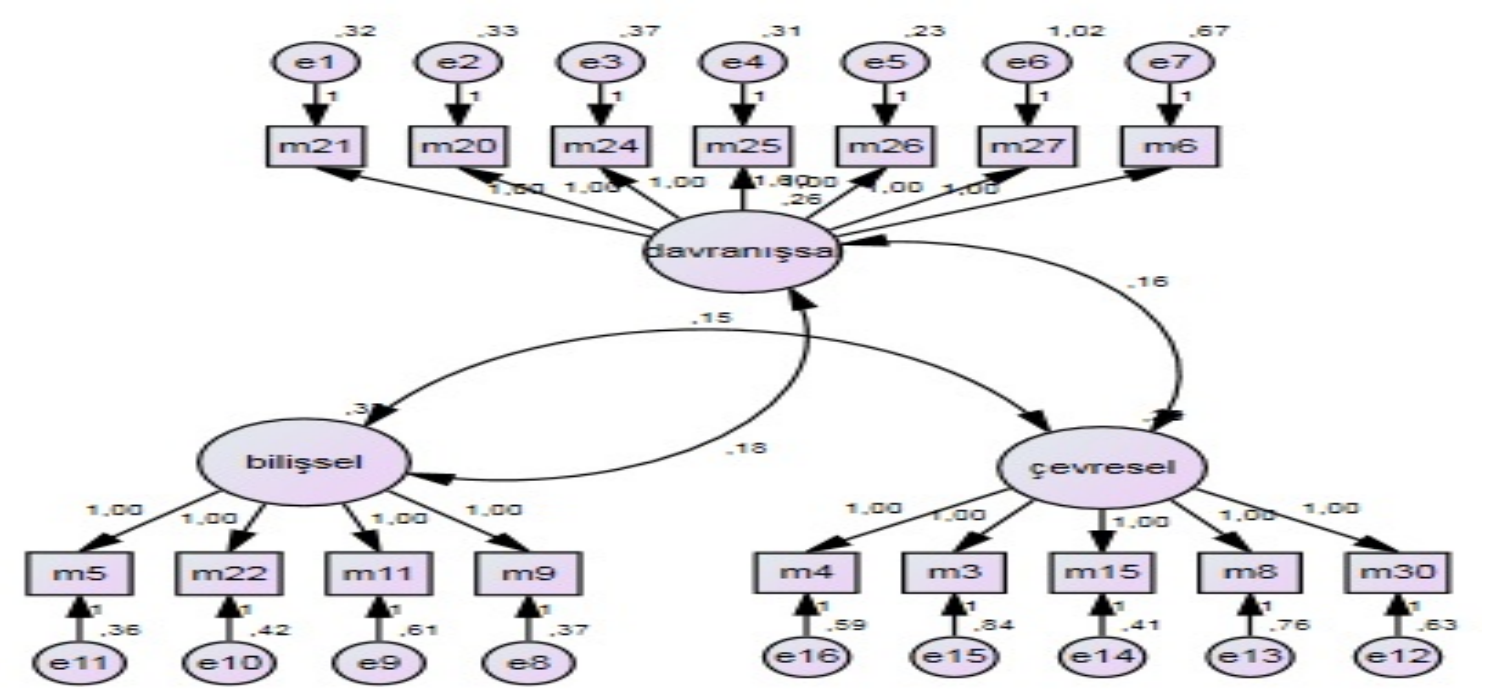


Açımlayıcı faktör analizleri sonuçlarına göre üç faktörlü yapı bulunmuştur. Ardından üç faktörlü ölçek modelinin geçerliğini belirlemek için Doğrulayıcı Faktör Analizi yönergeleri yerine getirilmiştir. Doğrulayıc1 faktör analizi sonucuna baktı̆̆ımızda ölçeğin iyi derecede uyumlu olduğu ifade edilmektedir: $(\mathrm{CMIN} / \mathrm{DF}=1.747),(\mathrm{CFI}=.930, \mathrm{GFI}=.924, \mathrm{NNFI}=.851, \mathrm{AGFI}=.909),(\mathrm{RMSEA}=.049, \mathrm{SRMR}=.061)$.

Hesaplanan Doğrulayıcı Faktör Analizi sonucu ölçme aracındaki madde faktör yüklerinin .43 ile .73 arasında değiştiği görülmüştür. Tablo 7 de faktör yükleriyle ilgili verilere yer verilmiştir.

Tablo 7. Madde Faktör Yükleri

\begin{tabular}{lll}
\hline Madde No & Faktör & Değer \\
\hline 21 & Davranışsal & .67 \\
20 & Davranışsal & .66 \\
24 & Davransşal & .64 \\
25 & Davranışal & .67 \\
26 & Davranışsal & .73 \\
27 & Davranıssal & .45 \\
6 & Davranışal & .52 \\
9 & Bilişsel & .68 \\
11 & Bilişsel & .59 \\
22 & Bilişsel & .66 \\
5 & Bilişsel & .69 \\
30 & Çevresel & .49 \\
8 & Çevresel & .45 \\
15 & Çevresel & .57 \\
3 & Çevresel & .43 \\
4 & Çevresel & .50 \\
\hline
\end{tabular}

Doğrulyıcı faktör analizi sonucunda davranışsal boyuttaki 7 madde, bilişsel boyuttaki 4 madde ve çevresel boyutta yer alan 5 madde ölçmek istediğimiz amaca hizmet etmektedir. Bu 16 madde bu ölçek modelinde istenilen akademik umutsuzluğu ölçmektedir.

\section{Sonuç, Tartı̧ma ve Öneriler}

Bu çalışmada, bir duygu olarak değerlendirilen umutsuzluğun akademik süreç veya ortamlardaki yansımalarını ortaya koymak amacı ile geliştirilen Akademik Umutsuzluk Ölçeği'nin psikometrik özellikleri belirlenmiştir. Akademik Umutsuzluk Ölçeği'nin geliştirilmesi, güvenirlik ve geçerlik analizlerinin incelenmesi için yapılandırılmış yol ile süreç aşamalar halinde takip edilmiştir. Bu süreç boyunca literatürün taranması, madde havuzunun oluşturulması, maddeler hakkında alan uzmanlarının görüşleri alınması, pilot uygulamanın gerçekleştirilmesi, maddelerin eksikliklerinin giderilmesi ve düzenlenmesi, ölçek formu uygulamasının yapılması, faktör yapılarının belirlenerek doğrulanması, madde analizleri, güvenirlik ile geçerliğinin sağlanması aşamalarıyla takip edilmiştir.

Akademik Umutsuzluk Ölçeği'nin geliştirilmesi sürecinde öncelikli olarak literatür taranıp umutsuzluk ve akademik umutsuzluk ile ilgili bilgiler toplanmıştır. Ardından öğrencilerin akademik umutsuzluk hakkında görüşleri ve literatürden yararlanılarak madde havuzu oluşturulmuştur. İlgili literatür esas alınarak oluşturulan 64 adet madde alanında uzman altı akademisyen tarafından birbirlerinden bağımsız bir şekilde değerlendirilmiştir. Yapılan bu değerlendirme işleminin ardından madde havuzunda bulunan 20 maddenin akademik umutsuzluğu ölçebilecek nitelikte olmadığı üzerinde karar verilerek ölçek maddeleri arasından çıkartılmıştır. Geriye kalan maddelerin dil bilgisel yönden gerekli düzenleme işlemleri yapılmış ve 44 maddelik Akademik Umutsuzluk Ölçeği Pilot Uygulama Anket Formu hazırlanmışır. 50 öğrenci üzerinde uygulanması sonucu yapılan geçerlik-güvenirlik analizleriyle nihai 30 maddelik ve Hiçbir Zaman (1), Nadiren (2), Genellikle (3), Her zaman (4) oluşumlu dörtlü likert tipi bir ölçek hazırlanmıştır.

Ortaya konulan 30 maddelik nihai Akademik Umutsuzluk Ölçeği Anket Formu 310 üniversite öğrencisi üzerinde uygulanmıştır. Akademik Umutsuzluk Ölçeği’nin faktör yapısını belirlemek amacı ile açımlayıcı faktör analizi (AFA) ve doğrulayıcı faktör analizi (DFA) gerçekleştirilmiştir. Açımlayıcı faktör analizi sürecinde 14 maddenin düşük faktör yük değerleri, nomolojik yetersizlikler ve binişiklik gibi nedenlerle ölçekte bulunan maddeler arasından çıkarılmasına karar verilmiştir.

Sonuçta, Akademik Umutsuzluk Ölçeği'nin üç faktörlü, 16 maddeden oluştuğu ve toplam varyansın $\%$ 48.399'unu açıklayan bir yapıda olduğu belirlenmiştir. Birinci faktör (davranışsal) toplam varyansın \% 31.248'ini, ikinci faktör (bilişsel) \% 9.140'inı ve üçüncü faktör (çevresel) \% 8.011'ini açılamaktadır. Faktör analizi sonucunda elde edilmiş olan bu üç faktör davranışsal, bilişsel ve çevresel olarak isimlendirilmiştir. 
Akademik umutsuzluk yaşayan öğrencilerde, bu üç alt ölçekteki umutsuzluk belirtileri görülebilmektedir. Yapı geçerliğini belirlemek amacıyla yapılan açımlayıcı faktör analizi sonucunda, Akademik Umutsuzluk Ölçeği'nin yapısının kabul edilebilir niteliğe sahip olduğu belirlenmiştir.

Ardından 16 madde üzerinden üç faktörlü yapının reel veriler ile uygunluğunu hesaplamak amacı doğrultusunda Doğrulayıcı Faktör Analizi (DFA) uygulanmaya çalışılmışıı. Aslında Açımlayıcı Faktör Analiziyle ulaşılan yapının geçerliğini net olarak ortaya koymak amacıyla Doğrulayıcı Faktör Analizi uygulanmıştır. Doğrulayıcı Faktör analiz sonucunda ölçekte yer alan bu 16 maddenin akademik umutsuzluğu hipotetik olarak ölçen bir yapı sağladığını bulgular sayesinde ortaya konulmuştur. Yani analiz sonucu elde edilmiş uyum indeksleri makul düzeyler içerisinde olduğu saptanmıştır. Açımlayıcı Faktör Analiziyle belirlenmiş üç faktörlük yapı Doğrulayıcı Faktör Analizi ile sınanarak yapının tutarlık özelliği gösterdiği sonucuna varılmıştır.

Yapı geçerliğinin sağlanmasının ardından, Akademik Umutsuzluk Ölçeği ile ilgili madde analizleri gerçekleştirilmiştir. Madde toplam korelasyonları .30 ile .60 arasında değiştiği belirlenmiştir. Ulaşılan madde toplam korelasyonlarının genel anlamda kabul gören .30 ölçüt sınırından yüksek değer aldığ1 görülmektedir.

Madde analizi sürecinin ardından, Akademik Umutsuzluk Ölçeği'nin güvenirliği iç tutarlık (Cronbach alfa) katsayısı aracilığ ile değerlendirilmiştir. İç tutarlık (Cronbach alfa) katsayısının değerlendirilip ortaya konulmasında .70 ve üstü değeri temel kıstas olarak ele alınmıştır (Creswell, 2012, 146-166). Bu açıklamalara göre, .838 olarak hesaplanan iç tutarlık (Cronbach alfa) katsayısı Akademik Umutsuzluk Ölçeği’nin güvenilir bir ölçme aracını meydana getirdiğini göstermektedir.

Bu çalışmadan elde edilen bulgulara baktığımızda Akademik Umutsuzluk Ölçeği’nin hem geçerli hem de güvenilir bir ölçme aracı olduğunu yansıtmaktadır. Böylece, Akademik Umutsuzluk Ölçeği üç faktörden oluşan ve 16 maddeli dörtlü likert tipi derecelendirmeye sahip bir ölçme aracıdır.

Ölçekte 1 madde olumsuz puanlanırken, 15 maddenin puanlamasında tersine çevirmek gerekmektedir. Geliştirilen ölçme aracından en düşük 16 ve en yüksek 64 puan alınabilmektedir. Yüksek derecede alınan puanlar birey açısından akademik umutsuzluk düzeyinin yüksek olduğunu işaret etmektedir. Akademik Umutsuzluk Ölçeği’nin, üniversite düzeyinde öğrenim gören öğrencilerin akademik umutsuzluk düzeylerinin incelenebileceği eğitimin yanında psikoloji temelli de araştırmalarda kullanılmasını sağlayabilecek geçerli ve güvenilir bir ölçme aracı geliştirildiği ifade edilebilmektedir. Akademik umutsuzluğun duyuşsal faktörler ile etkileşimi üzerinde bir incelenme önerilmektedir. Bu çalışmanın üniversite öğrencileri haricinde lise öğrencileri gibi farklı çalışma grupları üzerinde tekrarlanarak incelenmesi, geliştirilen Akademik Umutsuzluk Ölçeği'nin geçerlik ve güvenirliğinin daha net bir biçimde belirlenmesine olanak sağlayabileceği düşünülmektedir.

\section{Etik Beyan}

“Akademik Umutsuzluk Ölçeği: Geliştirilmesi, Geçerlik ve Güvenirlik Çalışması” başlıklı çalışmanın yazım sürecinde bilimsel, etik ve alıntı kurallarına uyulmuş; toplanan veriler üzerinde herhangi bir tahrifat yapılmamış ve bu çalışma herhangi başka bir akademik yayın ortamına değerlendirme için gönderilmemiştir.

\section{Kaynakça}

Abramson, L. Y., Metalsky, G. I. ve Alloy, L. B. (1989). Hopelessness depression: A theory-based subtype of depression. Psychological review, 96(2), 358.

Creswell, J. W. (2002). Educational research: Planning, conducting, and evaluating quantitative. Upper Saddle River, NJ: Prentice Hall.

Dilbaz, N. ve Seber, G. (1993). Umutsuzluk kavramı: Depresyon ve intiharda önemi. Kriz Dergisi, 1(3), 134-138.

Gölalmış Erhan, G. (2005). Zibinsel engelli çocuğu olan annelerin umutsuzluk, karamsarlke, sosyal destek alglarmm ve gelecek puanlarmin incelenmesi (Yüksek Lisans Tezi). Ankara Üniversitesi, Ankara.

Izgar, A. (2009). Engelli çocuğu olan ailelerin sosyal problem çözme becerileri ve umutsuzlluk dï̈reylerinin incelenmesi (Doktora Tezi). Selçuk Üniversitesi Sosyal Bilimler Enstitüsü, Konya.

Kline, R. B. (2015). Principles and practice of structural equation modeling. Guilford publications.

Melges, F. T. ve Bowlby, J. (1969). Types of hopelessness in psychopathological process. Archives of General Psychiatry, 20(6), 690-699.

Odacı, H., Kalkan, M. ve Çıkrıkçı, Ö. (2017). Akademik mükemmeliyetçilik ölçeğinin geliştirilmesi. Abi Evran Üniversitesi Krrşehir Ë̆itim Fakültesi Dergisi (KEFAD),18, 353-366. 
Ottekin, N. (2009). Ailelerinden ayr olarak öğrenim görmekte olan üniversite ögrencilerinin benlik saygzsı ve umutsuح̨luk düzeylerinin incelenmesi (Doktora Tezi). Selçuk Üniversitesi Sosyal Bilimleri Enstitüsü, Konya.

Şahin, A. (2002). ̇lahiyat fakültesi öğrencilerinin umutsuzluk düzeyleri üzerine bir araştırma. Necmettin Erbakan Üniversitesi İlahiyat Fakültesi Dergisi, 13(13), 143-157.

Şahin, İ., Zoraloğlu, Y. R. ve Fırat, N. Ş. (2011). Üniversite öğrencilerinin yaşam amaçları, eğitsel hedefleri üniversite ögreniminden beklentileri ve memnuniyet durumları. Kuram ve Uygulamada Eğitim Yönetimi Dergisi, 17(3), 429-452.

Şencan, H. (2005). Sosyal ve davramsssal ölçümlerde güvenirlik ve geçerlik. [Reliability and validity in social and behaviora]. Ankara: Seçkin Yayıncılık.

Taner, D. (2008). Öğretmenlerin umutsuə̧luk düzeyi ile okul kültürü arasındaki ilişki (Yüksek Lisans Tezi). Yeditepe Üniversitesi, İstanbul.

TDK. (2018). $\quad$ umutsuqluk, $\quad 15 \quad$ Kasım $2018 \quad$ tarihinde http:/ / www.tdk.gov.tr/index.php?option=com_gts\&arama=gts\&guid=TDK.GTS.5c0e44b7cbe678.36648929 adresinden alınd1.

Tümkaya, S. (2005). Ailesi yanında ve yetiştirme yurdunda kalan ergenlerin umutsuzluk düzeylerinin karşılaştırılması. Türk Ë̆itim Bilimleri Dergisi, 3(4), 445-457.

Uzbaş, A. (1998). Cocuklarn ögrenilmis çaresizlik davranıslarmm depresyon düzeylerine etkisi (Yüksek Lisans Tezi). Dokuz Eylül Üniversitesi, İzmir.

Ünal, A. (2006). İlköğretim öğrencilerinin gelecek ile ilgili umutlarnnn yapısal eşitlik modelleriyle belirlenmesi (Yüksek Lisans Tezi). Eskişehir Osmangazi Üniversitesi, Eskişehir.

Ünlüer, E. (2009). 2-6 yas arası otistik çocuğa sahip annelerin algiladıklar sosyal destek ve umutsu§luk düzeyleri arasindaki ilişkinin incelenmesi (Yüksek Lisans Tezi). Marmara Üniversitesi, İstanbul.

\section{EXTENDED ABSTRACT}

This research has been conducted to develop a measurement tool that can be used to determine individual differences in academic hopelessness levels and examine validity-reliability. The research was conducted with the data obtained from university students between the academic year of 2018-2019. The Academic Hopelessness Scale is a 16-item Likert-type scale. General screening model was used in the research. The Cronbach alfa coefficient, calculated to determine the internal consistency of the scale, is 83.As a result of the exploratory factor analysis made for purpose construct validity, three factors explaining $48.3 \%$ of the total variability were obtained. The three-factor structure was tested by confirmatory factor analysis and it was determined that the fit relationship was acceptable. The validity study shows that this scale distinguishes the groups which the level of academic hopelessness is expected to differ from each other.

The Academic Hopelessness Scale was developed to determine the academic hopelessness of the individual with behavioral, cognitive and environmental sub-dimensions. The scale consists of 16 items and three sub-dimensions. Students are given statements about their academic hopelessness, and how often they live, between 1 and 4, (4) Always, (3) Generally, (2) Rarely, (1) They are never asked to rate. The highest score is 64, and the lowest score is 16. The reliability of the Academic Hopelessness Scale was calculated by calculating the Cronbach's alpha internal consistency coefficient. In the validity study, Exploratory Factor Analysis and Confirmatory Factor Analysis were used for construct validity. SPSS 17.0 package program and IBM SPSS AMOS 22 were used for data analysis.

In order to see the status of the Academic Hopelessness Scale, which has been tried to be developed, both the factor level and the total, the corrected item total correlations between the scores of each item and the total scores of the students and the total scores of the factors were determined. On the other hand, Cronbah Alpha reliability coefficients were calculated based on the total factor of the items and within the factor. According to the results obtained, it shows significant correlations with the sum of the factors in which the individual substances were found. However, the total score shows a significant correlation with many other items. The Cronbach Alpha internal consistency coefficients of the Academic Hopelessness Scale for subscales were determined as .78 for Behavioral subscale, .74 for Cognitive subscale and .63 for Environmental subscale. When the internal consistency coefficients of the measurement tool are calculated, it is observed that the Cronbach Alpha value of the environmental subfactor is lower than the .70 value determined as the limit. The fact that the number of items in the environmental sub-factor is low (five items) can be shown as causing the internal consistency value to be low for the mentioned sub-dimension. The fact that the internal consistency coefficient of a measuring instrument related to sub-factors is cut-off point of .60 may be reasonable for reliability.

The results of confirmatory factor analysis indicated that the scale was in good agreement: (CMIN / $\mathrm{DF}=1.747),(\mathrm{CFI}=.930, \mathrm{GFI}=.924, \mathrm{NNFI}=.851, \mathrm{AGFI}=.909),(\mathrm{RMSEA}=.049, \mathrm{SRMR}=.061) . \mathrm{In}$ the process of the development of the Academic Hopelessness Scale, literature was searched primarily and 
despair and academic hopelessness were collected. Subsequently, a pool of substances was created by using the opinions of the students about academic hopelessness and literature. Sixty-six academicians from the field of study were evaluated independently from each other. After this evaluation process, it was decided that 20 items in the pool of material were not qualified to measure academic hopelessness and were excluded from the scale items.

The grammatical necessary editing procedures of the remaining items were made and the 44-item Academic Hopelessness Scale Pilot Application Questionnaire Form was prepared. As a result of the validity and reliability analyzes conducted on 50 students, a four-point Likert-type scale was prepared with the final 30 items and never (1), rarely (2), usually (3), always (4). The final 30 items of the Academic Hopelessness Questionnaire were presented to 310 university students. In order to determine the factor structure of the Academic Hopelessness Scale, exploratory factor analysis (AFA) and confirmatory factor analysis (CFA) were performed. During the exploratory factor analysis process, it was decided to subtract 14 items from the items on the scale due to low factor load values, nomological insufficiencies and overlap.

As a result, it was determined that the Academic Hopelessness Scale consisted of three factors, 16 items and $48.399 \%$ of the total variance. The first factor (behavioral) explained $31.248 \%$ of the total variance, the second factor (cognitive) $9.140 \%$, and the third factor (environmental) $8.011 \%$. These three factors which were obtained as a result of factor analysis were named as behavioral, cognitive and environmental. Students with academic despair may show signs of despair in these three sub-scales. As a result of the exploratory factor analysis conducted to determine the construct validity, it was determined that the structure of the Academic Hopelessness Scale was acceptable.

As a result of the calculated confirmatory factor analysis, item factor loadings in the measurement instrument ranged between .43 and .73. After construct validity, item analysis was performed on Academic Hopelessness Scale. Item total correlations ranged from .30 to .60. It is seen that the total correlations of the items reached are higher than the generally accepted .30 criteria limit.

After the item analysis process, the reliability of the Academic Hopelessness Scale was evaluated by the internal consistency (Cronbach alpha) coefficient. In the evaluation of internal consistency (Cronbach alpha) coefficient, the value of .70 and above is considered as the main criterion (Creswell, 2012). According to these explanations, the internal consistency (Cronbach alpha) coefficient calculated as .838 indicates that the Academic Hopelessness Scale was a reliable measurement tool. 